\title{
Change Phenomena of Spatial Physical in the Dynamics of Development in Urban Fringe Area
}

\author{
Batara Surya \\ Received: 3107 2015 / Accepted: 1012 2015 / Published online: 30122016 \\ C 2016 Faculty of Geography UGM and The Indonesian Geographers Association
}

\begin{abstract}
The study aims at analyzing change of spatial physical, spatial articulation, spatial structure, social and agglomeration and deagglomeration of function in the dynamics of development in the fringe area of Hertasning-Samata, Makassar City. Spatial physical changes are designated by the presence of new socio-economic functions that drive spatial structure changes, spatial articulation, social changes and agglomeration/deagglomeration of function in the fringe area of Hertasning-Samata. It applies quantitative and qualitative approaches (mixed method). Data is acquired from some sources and community informants living in the fringe area of Hertasning-Samata, Makassar City. Rapid and revolutionary spatial physical changes contribute positively to spatial structure changes, spatial pattern, agglomeration/ deagglomeration of area function. Spatial function change which had been dominated by commercial function becomes the determinant of social changes in the fringe area of Hertasning-Samata. Domination of mastery of reproduction of space by capitalism shows differences in mastery of reproduction of space significantly between space of capitalism and space of pre-capitalism. It sharpens economic stratum, status differences, between space of capitalism and space of pre-capitalism and sociocommunity classes. The dynamic of spatial physical change causes orientation shift to community activity which had run along dialetic of modernity and rationalization of action in local community.
\end{abstract}

Key words: Spatial physical changes, Spatial articulation, Agglomeration of function, Deagglomeration of function, Fringe area.

\begin{abstract}
Abstrak Penelitian ini bertujuan untuk menganalisis perubahan fisik spasial, artikulasi spasial, perubahan struktur ruang, perubahan sosial, aglomerasi fungsi dan dis-aglomerasi fungsi dalam dinamika pembangunan kawasan pinggiran HertasningSamata Kota Makassar. Perubahan fisik spasial ditandai dengan keberadaan fungsi-fungsi kegiatan sosial-ekonomi baru, mengondisikan perubahan struktur ruang, artikulasi spasial, perubahan sosial dan aglomerasi/dis-aglomerasi fungsi kawasan pinggiran Hertasning-Samata. Penelitian ini menggunakan pendekatan kuantitatif dan kualitatif (mixed method). Data diperoleh dari beberapa sumber dan informan komunitas yang mendiami kawasan pinggiran Hertasning-Samata Kota Makassar. Perubahan fisik spasial yang sangat cepat dan revolusioner berkonstribusi positif terhadap perubahan struktur ruang, pola ruang, aglomerasi/dis-aglomerasi fungsi kawasan. Perubahan fungsi ruang yang didominasi fungsi komersil menjadi determinan perubahan sosial pada kawasan pinggiran Hertasning-Samata. Dominasi penguasaan reproduksi ruang oleh kapitalisme menunjukkan perbedaan penguasaan reproduksi ruang yang sangat signifikan antara ruang kapitalisme dan ruang prakapitalisme, berdampak pada penajaman strata secara ekonomi, perbedaan status, dan kelas-kelas sosial komunitas. Dinamika perubahan fisik spasial menyebabkan pergeseran orientasi kegiatan komunitas yang berjalan sejajar dengan dialektika modernitas dan rasionalisasi tindakan dalam komunitas lokal.
\end{abstract}

Kata kunci: Perubahan Fisik Spasial; Artikulasi Spasial; Aglomerasi Fungsi; Dis-Aglomerasi Fungsi Kawasan Pinggiran.

\section{Introduction}

Hertasning-Samata area is in the urban fringe of Makassar City which is directly connected with Mamminasata Metropolitan area. This direct connection is, especially, with urban region of Sungguminasa City, Gowa Regency.

Batara Surya

Universitas Bosowa Makassar Makassar, Indonesia

Email: bataraciptaperdana@yahoo.co.id
It is identified that the fringe area of HertasningSamata faces rapid and revolutionary spatial physical changes, and it is designated by spatial function shift in this area for year period of 20042014. Spatial utilization shift in the fringe area of Hertasning-Samata is designated by land use conversion from productive farm land to residential area at a huge scale, education, office complex, shopping complex, services, hotels, and other commercial economic activities. This spatial function shift has an impact on spatial structure 
change, and it associates positively to social structure change in community who live in the fringe area of Hertasning-Samata. Social structure change in community of fringe area of HertasningSamata was initiated by orientation change to the activity of local community. Formerly, most of them worked as farmer, then it changes into urban industrial activity. Changing local community's orientation indicates changes of social order, social system, production organization system, and cultural pattern in community. The community was agrarian, and it turns to be urban industrial, heterogeneous, and multicultural community. It means that values and tradition of agricultural community has been replaced by value system of urban industrial community.

Spatial function shift in fringe area of Hertasning-Samata is characterized by linear spatial physical development, where the center point forms concentric spatial distribution pattern. This new formation is collectively becoming one with the existence of new residential area built up by developer. There are two factors that drive this process, they are: first, the presence of main road corridor in Hertasning-Samata which connects, second, the presence of the Islamic State University of Alaudin, in Samata, shopping centers, and large scale residential area construction. The two factors are embryo that directly creates agglomeration and deagglomeration of function in fringe area of Hertasning-Samata, Makassar City and surrounding urban area within Mamminasata Metropolitan.

Accellerated development in fringe area of Hertasning-Samata, Makassar City within Mamminasata Metropolitan is driven by spatial physical change and the existence of HertasningSamata road corridor which built up during 20042008 to connect Makassar City and Gowa Regency. This process has direct impact on increasing flow of goods and passengers compared to former flow. Accordingly, it becomes driving force of dynamic of development in fringe area of HertasningSamata. This indication is observable from decreasing farm land area sizes that were conversed into urban activities. Spatial utilization shift in fringe area of Hertasning-Samata is so significant that is designated by some developing urban functions. They are (1) large scale residential construction that occupies land area size around $752.83 \mathrm{Ha}$, (2) commercial and shopping center functions in an area of $11.12 \mathrm{Ha}$, (3) education function that occupies $35.59 \mathrm{Ha}$, (4) services and hotels that occupy $0.87 \mathrm{Ha}$. Besides, in the aspect of transportation infrastructure (road network), it was only $1.7 \mathrm{~km}$, and it is $5.06 \mathrm{~km}$ today. Further, population is growing too that it was only 117,625 people in 2004-2008, and it grows up to 181,372 people during 2012-2014; simply put, population increase is 63,747 people. This population increase signifies high urbanization and migration flow moving to fringe area of Hertasning-Samata, and it indicates suburbanization that occurs from time to time. The meaning there of spatial physical change that occurs rapidly and revolutionary becomes driving force of means of production to reproduction of space. It is predictable that the scale will be increasing over time. This condition then has an impact on agglomeration and deagglomeration of function in fringe area of Hertasning-Samata. It also makes social structure change in local community that was homogeneous, and the community turns to be heterogeneous and multicultural community where the changes run along dialetic of modernity and rationalization of action in local community.

Beyond the factors mentioned above, it emerges an interesting phenomenon in fringe area of Hertasning-Samata where building function is changed from shopping centers into other building functions like hotels, offices, café and restaurants. This condition specifically takes place through hout link corridor of Hertasning. Building use conversion directly affects traffic flow that will get stuck in the morning, noon, and afternoon, and it becomes routine in fringe area of HertasningSamata.

\section{The Methods}

This article is research findings given to the fringe area of Hertasning-Samata, Makassar City shown figure 1 . This area connects directly with urban area of Gowa Regency within Mamminasata Metropolitan. It applies qualitative phenomenological research for some reason as follows: (a) spatial physical change in fringe area of Hertasning-Samata is a phenomenon which is specific, arranged in complexity, and connected directly to urban area of Gowa Regency in Mamminasata Metropolitan, (b) phenomenon and dynamic occurred in fringe area of HertasningSamata is consistent, and the sequence is 
prominent as fringe area in Makassar City, (c) in context of spatial physical phenomena in fringe area of Hertasning-Samata, it is quite complex and revolutionary, (d) nature and characteristics in disclosure of meaning by phenomenological method aims at understanding a background or phenomenon that changes spatial function, spatial articulation, social change, dialetic of modernity, rationalization of community action, agglomeration and deagglomeration of function in fringe area of Hertasning-Samata.

Data analysis method applied here in is combination between quantitative and qualitative method (mixed method). Philosophical reason in combining these two approaches are: (1) triangulation logic; in this matter, qualitative research finding is re-checked by quantitative research, and vice versa in order to strengthen the findings validity, (2) quantitative and qualitative

research are combined to give a general overview,(3) quantitative research is applied to structural characteristics of social life, and qualitative research takes subject's quality as starting point, so these two approaches are attended collectively to execute the study, (4) quantitative research is applied in analyzing relationship of inter-alterations, qualitative research is applied to assist in harmonizing factors underlying constructed relationship, (5) quantitative approach is applied to reveal structural characteristics of social life in large-scale size, while qualitative approach tends to reach behavioral in small-scale size, so researcher makes an effort to reveal these two levels, so quantitative and qualitative guides are applied collectively, (6) reality occurred is not a single phenomenon, but it is plural phenomena that in purpose to disclosure the existence facts, it shall combine two approaches at different times, and (7) in order to obtain data of the two different realities, it needs combination of quantitative and qualitative methods.

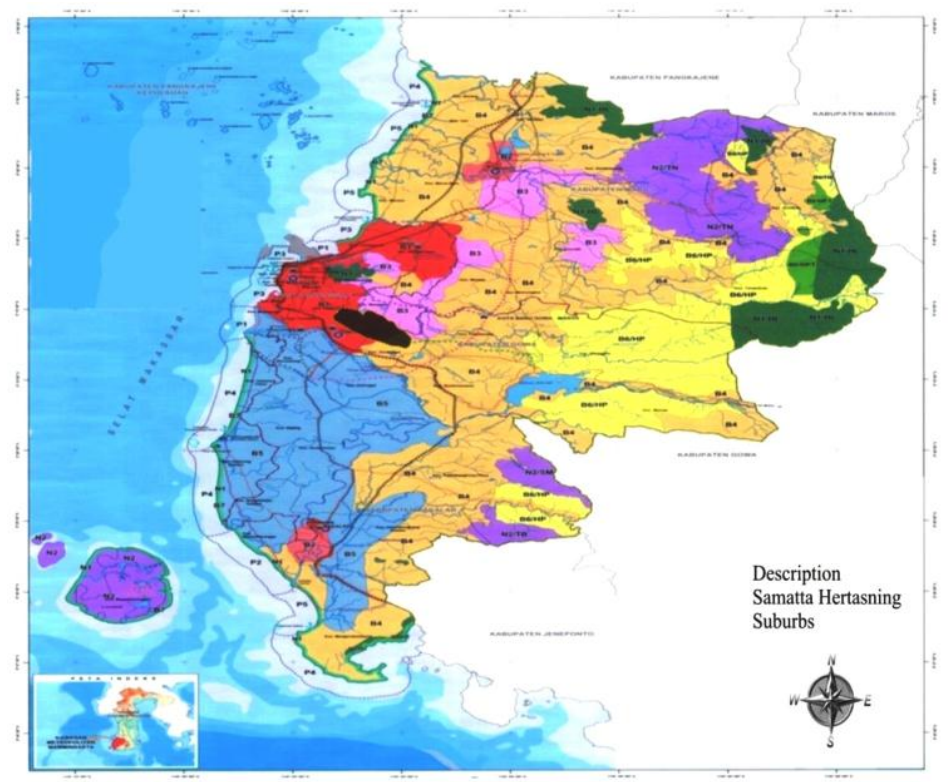

Figure 1. Fringe Area of Hertasning-Samata, Makassar City within Mamminasata Metropolitan as the Research Object

\section{Result and Discussion}

Spatial function shift in fringe area of Hertasning-Samata is used as determinant of rapid and revolutionary spatial physical change (year period of 2004-2014). It is designated by land use conversion which was dominantly occupied by productive agricultural land, and it changes into urban activities like services, education, commercial and residential area. Since the year period of 20042008, the occurred spatial utilization shift has an impact on spatial structure and spatial pattern changes in fringe area of Hertasning-Samata and surrounding urban area. This change is identified as dominant and driven by capitalism through penetration, invasion and dominance over mastery of reproduction of space. The presence of capitalism, mainly, is driven by an opinion that capitalism will make prosperity for those who have means of production. Determinant factor of spatial pattern change agrees with reality found in the field 
indicating that the shift of means of production to reproduction of space in fringe area of HertasningSamata occurs very fast and revolutionary (year period of 2004-2014). Accordingly, dominance over mastery of reproduction of space by capitalism creates morphological change in traditional rural area to urban industrial community through new spatial function development. Spatial structure and spatial pattern changes in fringe area of Hertasning-Samata shows a process of spatial articulation designated by collective coexistence of capitalist mode of production and pre-capitalist mode of production. This collective presence has in impact on social change of local community.

\section{Spatial Physical Changes, Spatial Articulation, Spatial Structure Change, and Social Changes in The Fringe Area of Hertasning-Samata}

Spatial physical characteristics and condition in fringe are of Hertasning-Samata in year period of 2000-2004 is characterized by dominance of agricultural and plantation land use; this land use is completely carried on by local community. Entry way to the fringe area of Hertasning-Samata is only accessible from A.P.Pettarani Street, Makassar City and Antang Raya lane in the south side of Makassar City. This condition illustrates that fringe area of Hertasning-Samata in former age is not in use yet and it was dominantly occupied by productive agricultural and plantation land area. Therefore, characteristics in the fringe area of HertasningSamata at that time were dominated by agricultural area (rural agrarian community). Spatial utilization shift in fringe area of Hertasning-Samata through land use conversion has an impact on agricultural and plantation land area size which were dominantly occupied this area, and this productive land is decreasing today.

Table 1 gives an overview that spatial utilization in year period of 2000-2004, spatial utilization function was dominantly occupied by agricultural activity in a land area size of $754.56 \mathrm{Ha}$ or around
$59.62 \%$ (figure 2). More over, land that is utilized for residential area is $361.41 \mathrm{Ha}$ or $28.56 \%$. Subordinate land use is used for socio-economic facilities by $0.07 \%$. Based on the data, it indicates that spatial function in fringe area of HertasningSamata is designated by two main activities conducted by local community, they are agricultural and plantation activity. Figure 3 shows in year period of 2008-2014, condition of spatial function in fringe area of Hertasning-Samata is dominated by residential area at a large scale by $752.83 \mathrm{Ha}$, trade function by $11.12 \mathrm{Ha}$, office function by $11.19 \mathrm{Ha}$, education function by 35.56 $\mathrm{Ha}$, and other functions by $3.29 \mathrm{Ha}$ This fact gives an overview that spatial physical change in fringe area of Hertasning-Samata occurs rapidly and revolutionary, and it will continue that will attract more migrants either in infiltrative manner or expansively.

Yunus [2008] proposes six factors that encourage spatial utilization shift in the fringe area; (a) accessibility factor; (b) public service factor; (c) characteristics of land; (d) characteristics of land owner; (e) the existence of regulation in regulating land use, and (f) initiative of developer. If the six factors are applied in development progress in the fringe area of Hertasning-Samata, they are very relevant and it is considered as the main stimulating factors of rapid and revolutionary spatial physical change in this area. Historically, early condition in the fringe area of HertasningSamata was identified as low economic value; then, when developer came and built up this area for education and commercial functions, this area turns to be an area for hotels, shopping centers and elite residential area and it is also supplied with sufficient, complete and modern means and infrastructure along with preparations of Mature Land Plot. This condition illustrates that the fringe area of Hertasning-Samata becomes a new region for migrants to live in and new growth center for Makassar City in Mamminasata Metropolitan. 
Table 1. Ratio of Spatial Utilization in Hertasning-Samata Area in Year Period of 2000-2004 and 2008-2014

\begin{tabular}{|c|c|c|c|c|c|}
\hline Land Use & $\begin{array}{c}\text { Land Area Size in Year } \\
\text { Period of } 2000-2004 \\
(\mathrm{Ha})\end{array}$ & $\%$ & $\begin{array}{l}\text { Land Area Size in } \\
\text { Year Period of } \\
2008-2014(\mathrm{Ha})\end{array}$ & $\%$ & Information \\
\hline Agriculture (Field) & 754.56 & 59.62 & 169.95 & 13.43 & Lessen \\
\hline Mixed farming & 95.90 & 7.58 & 35.17 & 2.78 & Lessen \\
\hline Residential Area & 361.42 & 28.56 & 752.83 & 59.49 & Expanded \\
\hline Trading & 1.66 & 0.13 & 11.12 & 0.88 & Expanded \\
\hline Vacant Land & 42.35 & 3.35 & 35.20 & 2.78 & Lessen \\
\hline Socio-Economic Facilities & 0.91 & 0.07 & 2.42 & 0.19 & Expanded \\
\hline Services and Hotel & - & - & 0.87 & 0.07 & Expanded \\
\hline Education & 1.68 & 0.13 & 35.59 & 2.81 & Expanded \\
\hline Office Complex & 7.07 & 0.56 & 11.19 & 0.88 & Expanded \\
\hline \multicolumn{6}{|l|}{ New Residential Area } \\
\hline Expansion and Mature & & - & 211.21 & 16.69 & Expanded \\
\hline \multicolumn{6}{|l|}{ Land Plot } \\
\hline Total & $1,265.55$ & & $1,265.55$ & & 00.00 \\
\hline
\end{tabular}

Source: Data Output from Monograph of Sub-district and Field Observation [2014]
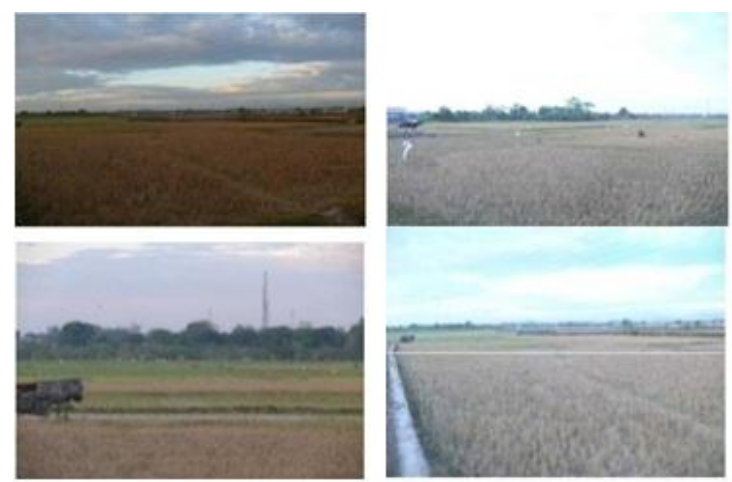
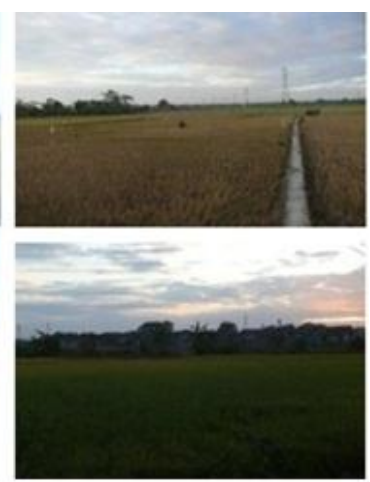

Figure 2. Condition of the fringe area of Hertasning-Samata which were dominated by productive agricultural land before spatial physical change in year period of 2000-2004
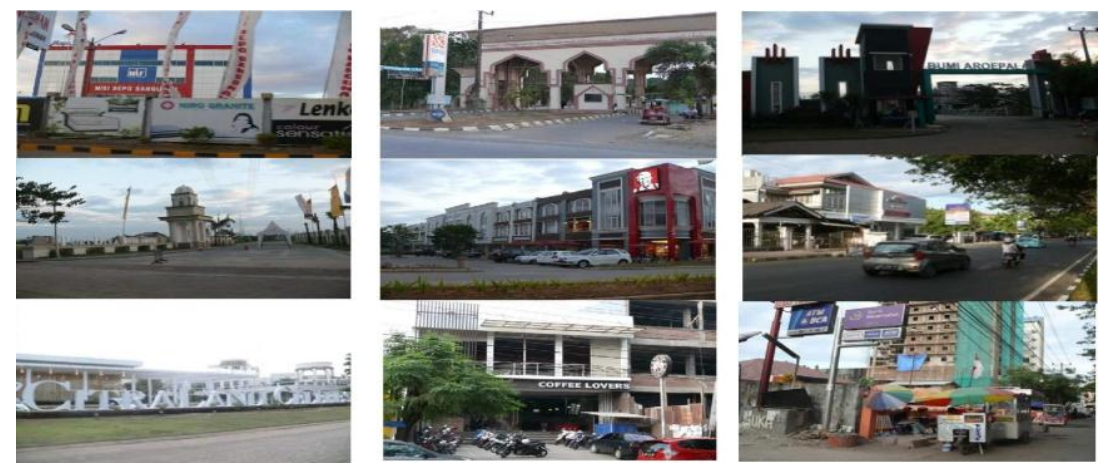

Figure 3. Spatial Expression in Hertasning-Samata after Spatial Physical Change in Year Period of 2008-2014 
There are two kinds of occurred spatial expression relating to spatial shift from means of production to reproduction of space in the fringe area of Hertasning-Samata, they are (a) lengthy spatial physical development (linear) and (b) spatial physical development concentrically. Forms of spatial expression in the fringe area of HertasningSamata occur separately and combine both kinds of expression. This reality is relevant with theoretical conceptualization of Yunus [2008] suggesting that centrifugal development in urban fringe area turns to be more complex in term of its spatial expression.
Lengthen centrifugal spatial physical development process expands the fringe area of Hertasning-Samata in Mamminasata Metropolitan. Consequently, it directly expands urban area of Makassar City that has direct connection with Gowa Regency. This process portrays that the lengthen and linear road corridor throughout Hertasning-Samata is a developed area in the direction of Gowa Regency. This lengthen road corridor has controlled either residential area or non-residential area, thus concentration of buildings is lengthen spatial pattern distribution in stead of widen pattern, patterns that evolve in a linear space described in figure 4 .

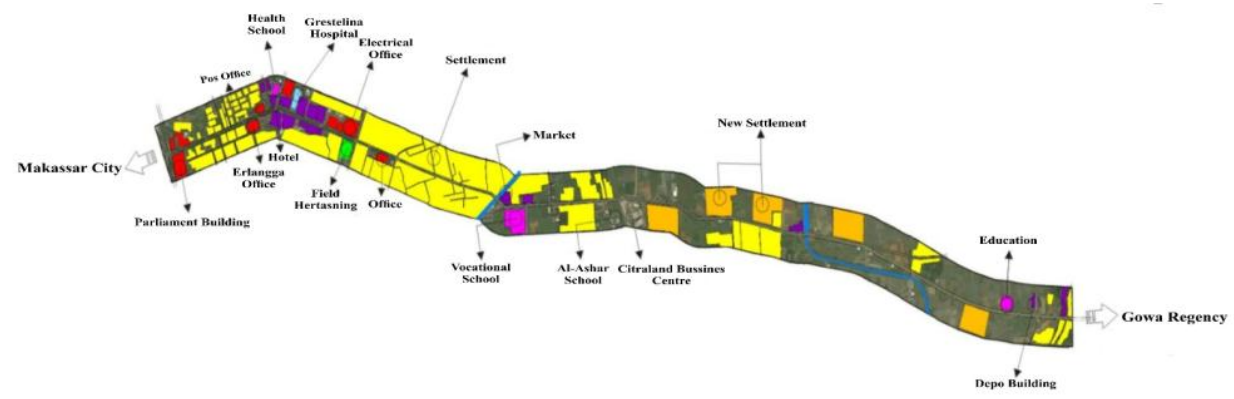

Figure 4. Condition of the fringe area of Hertasning-Samata which were dominated by productive agricultural land before spatial physical change in year period of 2000-2004

Centrifugal and concentric spatial physical development in Hertasning-Samata area is a form of urban area development that occupies the sides of developed area throughout main road corridor. This phenomenon occurs specifically in the center of Hertasning-Samata through accumulation of activity. The center point is designated by the presence of elite residential area named Citraland and shopping center; then, it is shadowed by presence of other various activities and new residential area that were built together. Based on this process, it emerges a concept where morphological control in the fringe area of Hertasning-Samata occurs easily since areas beyond the developed area are un occupied land with minimum obstruction. Topographic condition and characteristics of these areas are relatively flat that it makes development process performed by the developer easy.

Figure 5 shows the centrifugal and concentric spatial physical development in the fringe area of Hertasning-Samata has a close relationship with the life changes of migrants (infiltrative and expansive) and local community in social, economic and cultural life. The dynamics of development in the fringe area of Hertasning-Samata depicts a transitional flow from rural life to urban life. This reality is relevant with theoretical conceptualization on social zone changes developed by Giffor, R. [1987]; Castel, M. [1990] that the process leading to urban differentiation is designated by increasing scale in modern urban industrial society.

The fact found in the field depicts that direct impact as the conzequence of spatial physical change in the fringe area of Hertasning-Samata is a process of social change from traditional agrarian society to urban industrial society. This social change is designate by social life characteristics changing from traditional primitive society to modern life through social interaction and social adaptation between migrants and local community. This social change will keep increasing, and this increasing scale is reflected by lifestyle changes. It is relevant with theoretical conceptualization of Yunus [2006] that there are 3 kinds of expressions emerging collectively in the fringe area. They are 
constructed along with life style changes of society, they area (a) social rank, (b) urbanization, and (c) segregation. If these three factors are adapted to the fringe area of Hertasning-Samata, they will affect

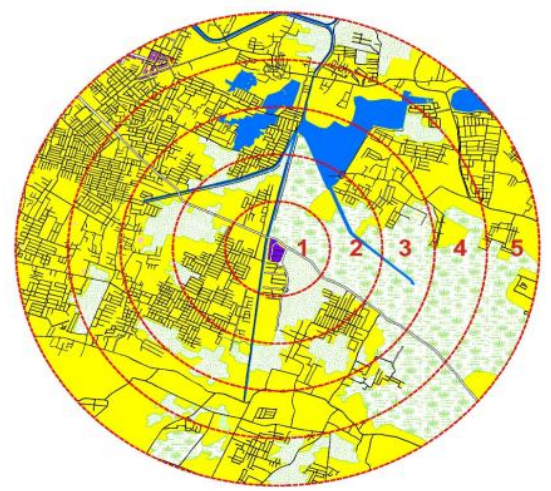

directly and the effect is observable. They also have significant effect on social system changes of society, and on powerlessness of local community to access resources of reproduction of space.

\author{
Eksplanation: \\ 1. CBD (Citraland) \\ 2. Recidential, Educational \\ 3. Recidential \\ 4. Recidential \\ 5. Recidential, Todopuli Traditional
}

Figure 5. Concentric Spatial Physical Development Distribution in Hertasning-Samata Area

In the schematic diagram (figure 6), it depicts that spatial utilization shift in urban fringe area was initiated by organizing production organization that is applicable in capitalist economic system. It also depicts that every society, excluding low economic status, is not involved in this process. Society that is dominantly involved in this process comes from minority groups, i.e. those people who have control over labors and goods they produced. The condition portrays that capitalists have arranged a profit-based policy to gain the greatest profit in is proved portraying that reposition and dominance over mastery of reproduction of space by capitalism in the fringe area of HertasningSamata will come to an end to encourage spatial pattern and spatial structure changes. Accordingly, reposition and reproduction of space Yunus [2005]. This concept dominance become a driving force of social changes in local community and encourage new social formation (capitalist social formation and pre-capitalis social formation).

Coexistence of capitalist and pre-capitalist mode of production in mastery of space creates differences in social stratum, status and classes. Economically, in the dynamics of society in fringe area of Hertasning-Samata, society is distinguished based on personal competence and skills. And, this phenomenon is an impact as the consequence of powerlessness of local community in accessing resources of reproduction of space in a spatial articulation. This process gives an overview that dominance of capitalist mode of production over pre-capitalist mode of production creates new social formation. This reality is relevant with theoretical conceptualization of Beilharz, P. [2005] stating that social formation, "transition", is mastered by an articulation of the two modes of production, and this formation indicates or will indicate the more dominating capitalist mode of production (figure 7). It also conforms to theoretical conceptualization of Millassaux, C. and Rey [1972] proposing "coexistence and hierarchy laws" where articulation is used to explain the more extensive concrete research, including imperialism, commodity production in the city, peasant, and undistributed spatial development.

Figure 8, above shows 4 dominant categories in orientation to the occupation had by local community today after spatial physical change. These are the percentage of every occupation: (1) $34.43 \%$ people are working as construction worker, (2) $18.85 \%$ people work as retailer in road link of Hertasning-Samata, (3) $15.16 \%$ people work as security guard, (4) $5.74 \%$. 


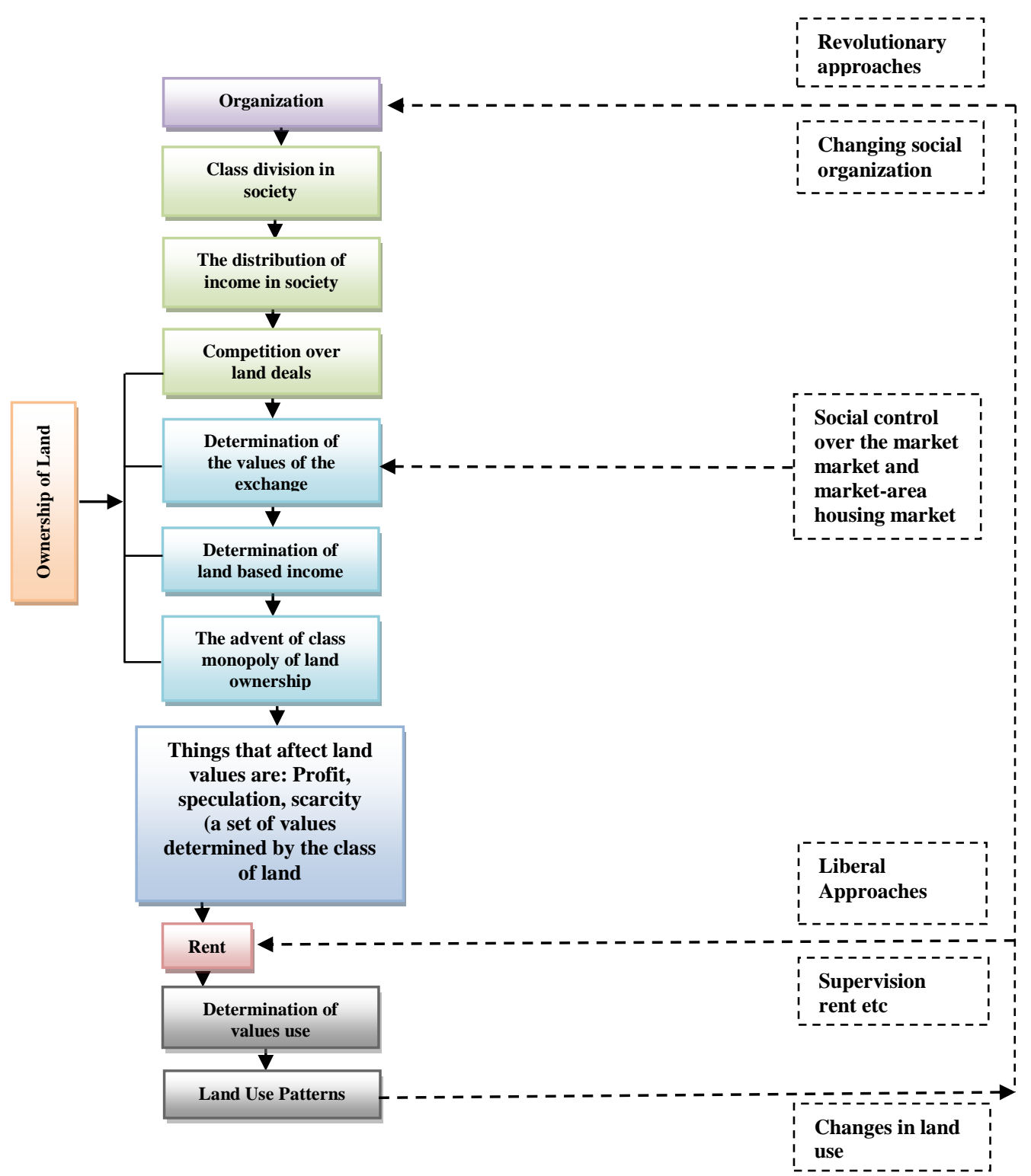

Figure 6. Spatial Structure in Hertasning-Samata (Adapted from Marxist Approach in Yunus, 2008)

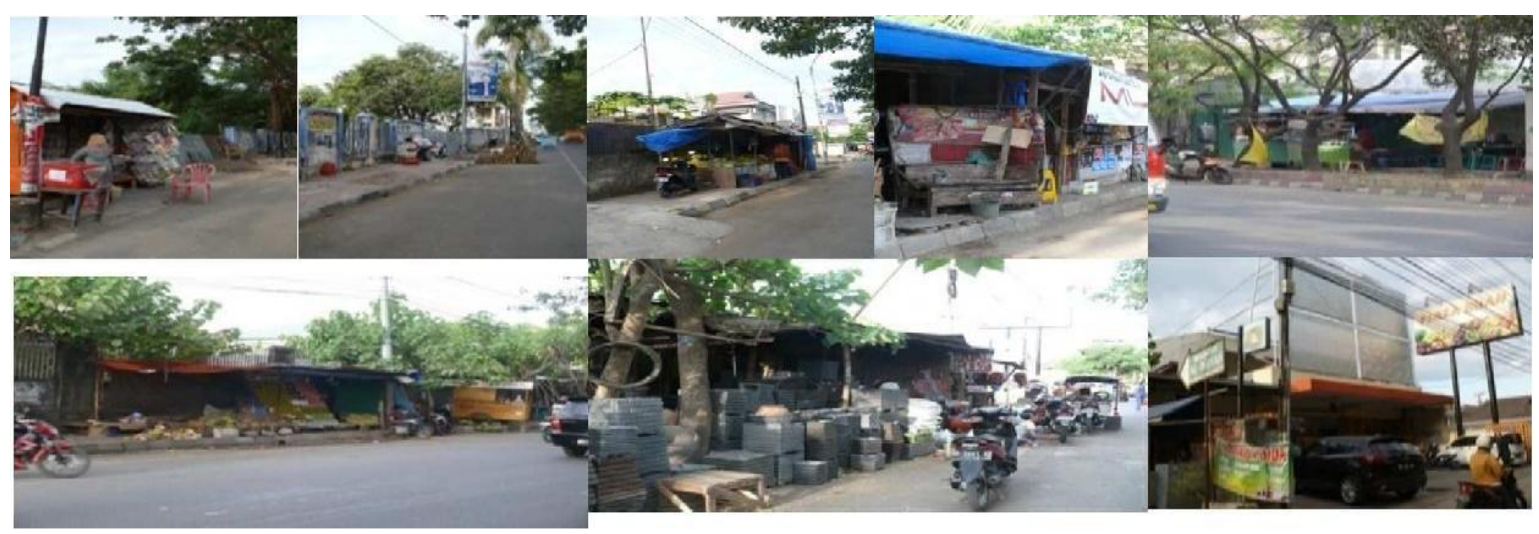

Figure 7. The Existence of Local Community after Spatial Physical Changes in the Fringe Area of HertasningSamata and Coexistence of Capitalist Mode of Production and Pre-capitalist Mode of Production in the Mastery of Reproduction of Space 


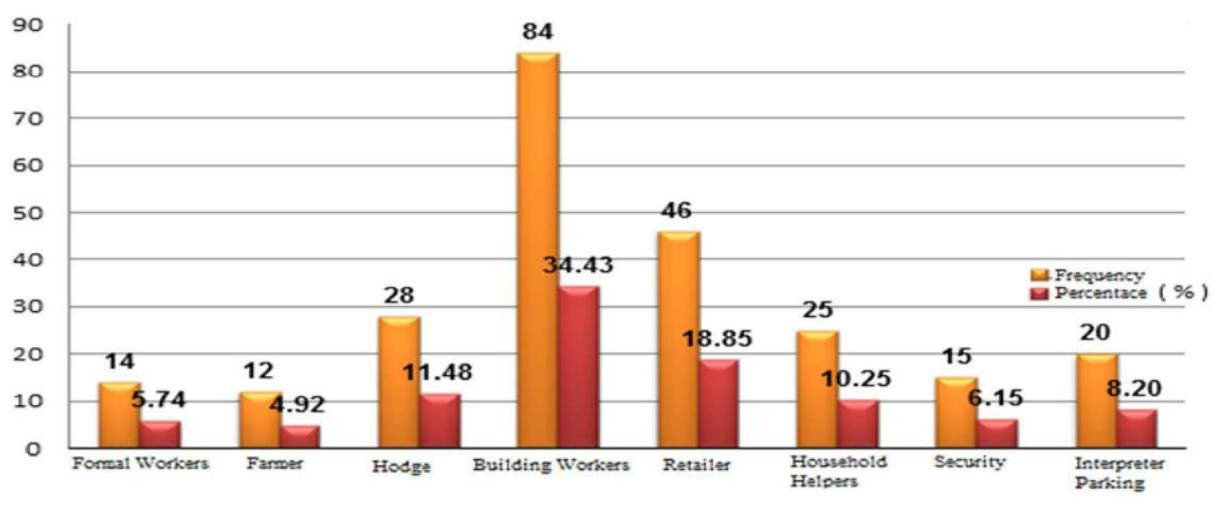

Figure 8. Current Occupations of Respondents after Spatial Physical Change

Spatial physical change in fringe area of Hertasning-Samata is not only the determinant of social change, but it also decrease agricultural products and make kin relationship of local community change. This condition is marked by scattering community that is so different from early condition before spatial physical change occurs. Kin relationship existing in community has also changed. A number of $81.97 \%$ people say that relationship of local community in one relationship does not function anymore. It is true that $15.57 \%$ of respondents still have a group, but it is not effective, or it does not function optimally to be a means of communication in regulating life of local community. It indicates that life of local community has been scattered; also, in the same time, it depicts that function of social bonding has not worked well to be a means of communication in establishing social relationship of among members in local community.

Modernization in the fringe area of HertasningSamata has an impact on dominance of capitalism over the existing reproduction of space that has dualistic nature in the process of production. This condition shows that activity in reproduction of capitalist space tends to be dominant more and more. Direct effect of this reproduction is on the chance and work opportunity that is possible to be achieved by local community. Local community shall have sufficient educational background.

Figure 9 gives an understanding that to achieve work opportunity in the fringe area of HertasningSamata, people shall have competence and skills with sufficient educational background, and it is not all local community are able to meet these requirements. Based on the effort performed by some local people, $48.77 \%$ respondents state that to work in today's developing activities, sufficient

formal education becomes a requirement. 31.56\% respondents, then, state that to work in today's developing activities, an effort to be done is by improving competence/skills in certain field. A number of $10.25 \%$ respondents state that to work in activities established by developer, people shall attend a course or training with sufficient formal educational background, while another 9.43\% respondents name other factors. What they meant in this case is a sort of connection and recommendation from local sub-district, neigh borhood council, and local citizen council.

The data found in the field portrays the migrants inhabiting the fringe area of HertasningSamata has orientation to occupation that is different from each other. Those migrants entering the area by infiltrative manner consist of Javanese who are generally working in construction sites, while a few of them work in informal and formal sector. Other ethnic group named Buginese is dominantly doing food stall business or retail, and a few of them are working in formal sector in new developing functions. Makassar people from Gowa Regency are dominantly working in construction built up by developer. The migrants who enter expansively and live in elite residential area are dominantly working in trade sector like shopping centers and other commercial activities. Process of social adaptation conducted by migrants is designated by occupational differentiation based on income, and it relates to the increasing urban industrial labor status and class. Development of new functions depicts capitalist mode of production that is dominant in mastery of reproduction of space. Consequently, it creates a 
space representationally as a media to process adaptation between migrants and local community. The reality is relevant with theoretical conceptualization of Lefebvre Ritzer [2008] suggesting that a space creates capitalist system, class structure in economic system, and representation of elite space that dominate spatial

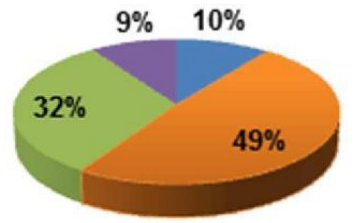

practice and representational space and real space to hold the dominance. It signifies that capitalism with mastery of technology will be always dominant over and over that the process of social adaptation is an effort to stir capitalist mode of production through exploitation of labor in purpose to gain the greates profit.
Figure 9. The Effort Performed by Responden
Based on the Table 2, some interpretation may be proposed. First, sidewalk vendor business established by local community depicts moderate adaptive capacity, while mastery of reproduction of space is low. This reality is relevant with theoretical conceptualization of Marx Suseno [2005] proposing that a group of people will do as their primary needs to defend themselves. Thus, high class people will certainly defend their position; conversely, low class people are trying to change their depressed condition. That is to say, if spatial physical change occurs rapidly and revolutionary in Hertasning-Samata area, adaptation process will be faced by local community in which they are forced to respond stimulus of environmental change. Accordingly, the reality completely affirms premise of Weber [2007], that affective rationality/rationality instrument is the most rational elements of consideration regarding the preferred means and action. This process of adaptation, then, is also relevant with theoretical conceptualization of Hawley in Beilharz [2005] that human behavior is a part of complexity in ecosystem. Accordingly, process of local individual social adaptation is indicated by the developing business, and one of them is informal sector business (sidewalk vendor) in pre-capitalist social formation. The collective occurrence of dialetic of modernity and spatial articulation which is marked by interaction between individual and his

\section{Following
courses and \\ Following \\ Formal \\ Education \\ Improving the \\ skills, expertise in \\ a particular field}


responding the rapid and revolutionary spatial physical changes in Hertasning-Samata. More over, tendency of this local community is separated from life of group, and they draw a line between their life and the changing environment. The reality is relevant with theoretical conceptualization of Gifford [1987] that personal space is a space surrounding individual, and this area must not be intervened by other people. Accordingly, spatial physical change that occurs as penetration of capitalism will force local farmer to step aside from Hertasning-Samata. This process is noticeable from theoretical conceptualization of Miles, B.M. [2007] that excessive or undesirable stimulation will create arousal/obstacle in adaptive capacity. This case, as well case occurred in Indonesia, is relevant with the findings of Habermas, J. [2007] stating that powerlessness in adaptation encourage person to get privacy by re-managing physical setting or move in other area. This process makes adaptive capacity of local community-who take agricultural business-low. They not only perform a life that is separated from new social formation, but also prefer to migrate to Gowa Regency.

Fourth, spatial physical change that occurs rapidly and revolutionary in Hertasning-Samata area through penetration of capitalism lead to modernization which afterwards process spatial articulation. There are two categories of adaptive capacity performed by local community in capitalist social formation, they are: (a) in residential construction, people from local community are participating in this activity either as worker or skilled labor (carpenter or bricklayer). Individual adaptive capacity of local community in this activity is high, but their mastery of reproduction of space is low, (b) in commercial business activity created by capitalism, there occurs a process of adaptation performed by individual of local community, especially in commercial business activity. Individual adaptive capacity of local community in this category is moderate, while mastery of reproduction of space is low. The reality conforms to theoretical conceptualization of Wolf, M. [2007], that the driving force at the back of capitalist expansion is in the structure of precapitalist mode of production to affect process of articulation. It signifies that the development of new functions in Hertasning-Samata drives the process of spatial articulation and leads to dominance of activity over reproduction of space of capitalism. Consequently, this process repositions individual of local community to be ready to exploited worker. The reality fully affirms theoretical conceptualization of Meillasoux and Rey [1972] where transition to former capitalism is not the product of capitalism itself, but a product of combination between particular pre-capitalist mode of production and how to articulate capitalism.

Therefore, it can be concluded that spatial physical change in Hertasning-Samata creates different adaptive capacity performed by local community. The reality also strengthen premise of Harvey [2009] that under development and poverty are not the impact of personal and institutional failure, but it is driven by coexistence of capitalist organization within a society. By having this articulation, capitalist mode of production leading to reproduction of space makes social change happen, and it also becomes the driving force for new social formation in Hertasning-Samata area.

Table 2. Ratio Between Capacity of Adaptation and Mastery of Reproduction of Space in the New Social Formation in Hertasning-Samata

\begin{tabular}{lcc}
\hline Orientation to Activity Local Community & \multicolumn{2}{c}{ The New Social Formation } \\
\cline { 2 - 3 } & $\begin{array}{c}\text { Adaptive } \\
\text { Capacity }\end{array}$ & $\begin{array}{c}\text { Mastery of Reproduction of } \\
\text { Space }\end{array}$ \\
\hline Sidewalk vendor (non-formal) & Moderate & Low \\
Parking lot attendant in economic activity & High & Low \\
functions & Low & Low \\
Farmer in subsistence farming & High & Low \\
Construction Worker & Moderate & Low \\
Formal Employee & &
\end{tabular}

Source: Primary data [2014] 


\section{Dialetic of Modernity, Social Change and Rationalization of Communal Action}

Spatial physical change in Hertasning-Samata area develops capitalist mode of production and pre-capitalist mode of production. Success of industrialization in the developing country is determined by coexistence of native pre-capitalist social formation and incoming capitalist social formation through process of penetration, invasion, dominance and final process of succession. Industrial transformation in Hertasning-Samata changes social structure in local community, and it leads to new social formation. The principal element in native pre-capitalist social formation affecting significantly coexistence is rationalization to action which is built up upon "sipa'paccei". Maintained understanding to the value of "sipa'paccei" in current local community becomes stimulator and motivating force in community to act upon rationality which was constructed by spatial physical change in Hertasning-Samata area. Modernization in Hertasning-Samata portrays development leading to complex urban work system. Accordingly, social reality which is established by pre-capitalist social formation will be exist and grow up in structuralist mode of social world objectively, though in the process of development, capitalist mode of production will be still dominant in new social formation. The reality is relevant with theoretical conceptualization of Dukheim [1986] that social reality objectively exists, while the meaning comes from subjective relationship (individual). These subjective values, then, will face dialectic tension in an objective condition. Therefore, what is proposed by Marx in Suseno [2005] on dialectic between individual with environment in the process of spatial physical change in Hertasning-Samata has lost direction and formation as the effect of materialism. In the process of spatial physical change which happened fundamentally and revolutionary, what would emerge is dialectic of modernity. It is created by the development of new material-based functions. The process stimulates local community to hold their existence based on the existing principle values to engage in rationalization to action.

Spatial physical change is determinant of social formation change, and it changes process of social interaction and social adaptation. Social formation change was initiated by single social formation, and it turns to multiple social formation indicating differences in social interaction process between local community and migrants; and it is assessed based on intensity of social interaction and emerging characteristics. Difference in social interaction in this new social formation is built up upon orientation to subsistence production and commercial in pre-capitalist social formation. In orientation to subsistence production, social interaction is based on kinship and family relationship in daily life. This condition depicts function and role of actor in the process of social interaction with orientation to subsistence production is in a same position and status which were built up upon values of togetherness and blood relationship (one lineage). The emerging characteristics are kinship and family relationship, willingness to meet each other, personal face-toface relationship at a high frequency, and spontaneous social relationship that occur intimately.

Spatial physical change that delivers new social formation in Hertasning-Samata triggers a process of social adaptation between migrants and local community in responding environmental changes. Process of social adaptation is designated by migrants who enter the area in infiltrative manner toward local community. It is performed by establishing mutual social relationship (symbiosis of mutualism). Strategy of social adaptation performed by infiltrative migrants is not only by living together with local community, but also willingness to participate in routine activities like volunteer work to keep surrounding residential area safe. They also make positive and mutual business relations for their business. Social adaptation performed by local community responding to infiltrative migrants is by making residential area/lodgings available in one residential area in addition to the local community's willingness to make mutual business relations (symbiosis of mutualism). This condition portrays mutual acceptance between both groups of people (local and infiltrative migrants). In fact, they come from different ethnic group and lineage, but social relationship is established well based on togetherness principles in purpose to improve prosperity in one new unity.

Accordingly, it can be concluded that if spatial physical change becomes the determinant of social formation change, it shows coexistence of precapitalist and capitalist social formation through 
process of spatial articulation in mastery of reproduction of space which does not work well. It also creates differences in the process of social interaction and social adaptation between local community and migrants (either infiltrative or expansive migrants) in Hertasning-Samata.

Based on the Table 4, some interpretation may be proposed. First, initial social stratification born in local community was characterized by land ownership dominance, and it leads to be complex as triggered by structural change in land ownership. Changes in this stratification involve work system, land ownership system and work relationship pattern. This phenomenon generates differences of economic-based social stratum in local community. Accordingly, changes occurred in this area is a kind of desirable change, and it is completely affected by the presence of capitalism which has a role as an agent of change. The government believes that capitalism will be able to engineer spatial physical change. This spatial physical change, later, will create a complexity and stimulate social stratification in local community in the fringe area of Hertasning-Samata. Second, recent developing social stratum is dominantly affected by spatial physical change, and it creates differences of orientation to job in local community. Third, the produced social relationship is highly affected by differences of orientation to local community's activity. Fourth, the power structure-social status, in this case-in local community is no longer determined by lineage, but it is built up upon competence and achievement achieved by local community; and, Fifth, variants in wealth in local community is determined by ability in responding to environmental change stimulus. The five factors create social stratification in local community in habiting the fringe area of Hertasning-Samata as the consequence of spatial physical changes.

\section{The Social Status Change}

Social status change in local community in Hertasning-Samata is determined based on 2 categories; they are (1) status that is achieved by lineage, and (2) status that is achieved based on achievement achieved by local community after spatial physical change.

Based on the Table 4, some interpretation may be proposed. First, initial social stratification born in local community was characterized by land ownership dominance, and it leads to be complex as triggered by structural change in land ownership. Changes in this stratification involve work system, land ownership system and work relationship pattern. This phenomenon generates differences of economic-based social stratum in local community. Accordingly, changes occurred in this area is a kind of desirable change, and it I completely affected by the presence of capitalism which has a role as an agent of change. The government believes that capitalism will be able to engineer spatial physical change. This spatial physical change, later, will create a complexity and stimulate social stratification in local community in the fringe area of Hertasning-Samata. Second, recent developing social stratum is dominantly affected by spatial physical change, and it creates differences of orientation to job in local community. Third, the produced social relationship is highly affected by differences of orientation to local community's activity. Fourth, the power structure-social status, in this case-in local community is no longer ownership to the means of production. The reality is relevant with theoretical conceptualization of Maslow Geertz, C. [1965]; Gidden, A. [2008] that individual will move toward hierarchal level in purpose to fulfill his needs.

\section{The Social Change Process}

The social change process describes differences. Below are two characterizations as distinctive element: (1) based on social characteristics, this differentiation is created by difference of job that creates different perspective and social behavior pattern in local community. Belong this category is different role, prestige and power (industrial labor behavior is totally different from behavior performed by farmer). The reality is relevant with theoretical concept-tualization of Weber [2007]; Manning, C. Effendi, T.N. [1996] proposing four criteria of social class based on cultural characteristics. It affirms that the condition is closely related to world view between local community and migrants regarding values they obey in life of community such as religious, kinship system, steadiness, and tena city.

\section{The Social Order Changes}

Migration to the fringe area of HertasningSamata directly contributes positively to social system changes in local community. It is observable in interpersonal and community relationship 
patterns in responding to spatial physical changes, and the pattern also affects significantly social structure change in local community. Social structure change in local community is made by the developing status, roles and stratification differences that construct differences of ideals, goals and aims of life in local community. The development relates to the developing system in division of labor as the effect of spatial physical change. Complexity of roles, status and stratification differences heads for characteristics of urban industrial community. There are some collective community characteristics indicating the forming elements of social system as follows: first, the presence of division of labor; second, the existence of interpersonal dependence; third, the existence of cooperation; fourth, the existence of two-way communication; fifth, the existence of interindividual function differences. This reality affirms theoretical conceptualization of Amin, et al. [2002] that social system consists of members of society who perform different activities or take diverse roles in general framework of division of labor. It can concluded that social system change in local community of the fringe area of HertasningSamata affects directly work system in local community where roles, status and stratification differences contributes positively to social relationship pattern and social pattern. Accordingly, social system change is the trigger of new social system in local community of the fringe area of Hertasning-Samata.

Table 4. Social Status of Local Community before and after Spatial Physical Change in Hertasning-Samata Area

\begin{tabular}{lcc}
\hline Former Social Status & Frequency & $\%$ \\
\hline Farmer & 132 & 54.10 \\
Trader & 68 & 27.87 \\
Farmhand & 44 & 18.03 \\
Total & 244 & 100.00 \\
\hline Current Social Status & Frequency & $\%$ \\
\hline Informal Sector Business (Sidewalk vendor) & 67 & 27.45 \\
Parking Lot Attendant & 98 & 40.16 \\
Construction Worker & 40 & 16.39 \\
Urban Formal Worker & 25 & 10.24 \\
Farmer & 14 & 5.73 \\
Total & 244 & 100.00 \\
\hline
\end{tabular}

Source: Primary data [2014]

\section{The Cultural Pattern Changes}

Spatial physical change in the fringe area of Hertasning-Samata which drives migration directly changes social values and social norms in local community. Expansive migration at a large scale makes social life of local community change, and it is initiated by structural changes of land ownership. The reality conforms to theoretical conceptualization of Armstrong, W.R. dan Terry McGee. [2002]; McGee, T.G. [1971] that social change leads to modification in human life patterns caused by internal or external causes. It signifies that spatial physical change which stimulates migration has a simultaneous effect on the changes of existence of local community. This obvious condition is visibly observable based on physical relationship between local community and migrants that it has tendency to affects reciprocally. It means that every community will have influence over each other, but they will also accept the influence from the other (process of spatial articulation).

Agglomeration and Deagglomeration of Function in The Fringe Area of HertasningSamata

Agglomeration of function taking place in the fringe area of Hertasning-Samata tends to 
industrial state where the activity is centralized in an area or zone based on spatial function equipped with means and infrastructure. This process creates economic value to potential land and location in the fringe area of Hertasning-Samata where the area is so strategic in Mamminasata Metropolitan. Thus, the development in fringe area of Hertasning-Samata aims at not only improving functions and roles of transportation, but also affecting spatial structure in Makassar City and Mamminasat Metropolitan. The areas with transportation throughout road corridor of Hertasning-Samata will have different physical growth compared to surrounding areas. The reality affirms theoretical conceptualization proposed by Yunus [2008] that spatial structure creates spatial dispersion pattern such as starshaped pattern/octopus-like pattern.

Agglomeration/deagglomeration of function occurred in the fringe area of Hertasning-Samata involves 4 main factors as the determinant as follows: (1). Special and particular facilities, (2) External economic factors, (3) Compromising factors for dissimilar inter-functions, and (4) Different function economic capacity factor. It is found that spatial physical change is functioned as the determinant of deagglomeration of function which is initiated by land ownership status changes and land use conversion; the land was dominated by agricultural function, and it changes into commercial and residential functions. This process converses means of production to reproduction of space in the fringe area of Hertasning-Samata. It is designated by the presence of unlike socio-economic activity functions where the functions are structured well (mixed space use), but the location is so close. That is to say, when coexistence of the two different modes of production, mastery of reproduction of space is dominated by capitalist social formation, and spatial articulation toward the two types of social formation are not run well, it will affect the presence of formal space in one side and nonformal space in the other side. Consequently, it has an effect on deagglomeration of spatial function in Hertasning-Samata area.

\section{The Implication of The Findings}

The study particularly reveals new discourse in city and zone planning. In profession of city and zone planning, especially in spatial zoning plan and fringe area development concerning on urban spatial analysis, there is an indication that city and zone planner is insufficiently motivated about upcoming social aspect and social effect as the consequence of spatial physical change and land use conversion. Focusing on social aspects is required, especially in the concept or formulation of spatial zoning plan. Therefore, the findings imply a consideration for spatial zone planner, specifically urban zone planning, that sociocultural aspect-particularly which relates to needs compliance of local community - is an important part of basic principle for the future urban fringe spatial zoning plan.

By applying urban spatial articulation concept, the third pillar in new urban development, i.e. the formation of social cohesion, will be constructed with an effort to prevent social conflict derived from imbalance urban land ownership. This social perspective shall be tailed by social life quality improvement, especially in urban marginal group who generally, they are subordinate people in urban social formation. Conventional urban spatial zoning planner, generally, is incapable of taking marginal group's space needs into consideration. Consequently, they forcefully occupy the remaining area like river bottom, roadsides, and unoccupied derelict land. Spatial articulation concept stands apart from a just pro-poor concept or stands up for the poor in the city. It is a concept for the poor who truly exist in the new social formation. It is also a concept where the poor will defend or, if it is necessary, they will take the land away illegally in purpose to show their existence and hold their coexistence among "capitalist" spaces surrounding them. Thus, spatial articulation concept suggests moderate solution. In one side, spatial zoning plan gives space for dominant sector (capitalist), and in other side, it guarantees mastery of social space for those who are subordinated (pre-capitalist). Accordingly, social cohesion as one of the three pillars for urban development, especially in the fringe area that will be changed into a new city, will be preserved and kept alive. Spatial articulation concept suggests urban spatial plan model by considering functions of everyone's activity in social formation in purpose to obtain effectiveness and efficiency in urban spatial pattern.

\section{Conclusion}

Rapid and revolutionary spatial physical change 
in the fringe area of Hertasning-Samata causes spatial function shift, and it affects significantly land use conversion. The effect is designated by capitalist dominance over mastery of reproduction of space. The change contributes positively urban spatial articulation process. The occurrence of spatial articulation in the fringe area of HertasningSamata portrays two kinds of mode of production, i.e. capitalist mode of production and pre-capitalist mode of production which run along collectively. Difference of mastery of reproduction of space which is dominated by capitalist mode of production creates spatial structure and spatial pattern changes in the fringe area of HertasningSamata. The area was rural agrarian community, and it turns to be complex urban community.

Spatial structure change was initiated by socioeconomic spatial function shift in the center of Makassar City. The change then leads the fringe area of Hertasning-Samata to a new growth center which directly affects spatial structure change in Mamminasata Metropolitan. The presence of commercial economic activity functions and large scale residential area becomes the driving force of social change in local community. Social change in local community was initiated by difference of orientation to job; it was rural agrarian community, then it leads to urban industrial community which is dominated by occupational orientation to construction sector. This orientation change is an adaptive response and rationalization of action performed by local community to environmental change stimulus. The social change contributes positively the dynamics of fringe area, dialectic of modernity, social order change, social system, social structure and cultural pattern in local community.

The development of functions in social activity, commercial economic function, and the existence of large scale residential area cause agglomeration of function in the fringe area of Hertasning-Samata. It also has multiplied effect on spatial functions which have linkage with either the structure or function (urban system). At the same time, there occurs deagglomeration of different inter-function as the consequence of mastery of space in formal manner and mastery of space in informal manner. The process contributes positively to the height of traffic volume and traffic jam throughout Hertasning-Samata road corridor.

\section{References}

Amin, Ash and Thrift, Nigel. (2002). Cities Reimaging the rural, Polity Press.

Armstrong, W.R. dan Terry McGee. (2002). "A Theory of Urban Involution." Hlm 220-234 dalam Hans-Dieter Ever (ed.), Sociologi of South-Eats Asia: Reading on Social Change and Development. Kuala Lumpur : Oxford University Press.

Beilharz, P. (2005). Teori-Teori Sosial (terjemahan oleh : Sigit Jatmiko. Judul asli : Social Theory) Penerbit. Pustaka Pelajar.

Castel, Manuel. (1990). Global Restruturation and Territorial Development, Blackwell.

Durkheim, Imile. (1986). Durkheim dan Pengantar Sosiologi Moralitas. Disunting oleh Taufik Abdullah dan A.C. van der Leeden. Penerbit : Yayasan Obor Indonesia.

Geertz, Clifford. (1965). Deep Play: "Notes on the Balinese Cockfight". Clifford Geertz (ed.), The interpetation of culture: Selected Essay (hlm 412453). New York: Basic Books.

Gidden, A. (2008). Social Theory Today : Panduan Sistematis Tradisi dan Tren Terdepan Teori Sosial. Penerbit: Pustaka Pelajar

Giffor, R. (1987). Enviromental Psycologi : Principle and Practise, Boston: Allyn ad Bacon, Inc.

Habermas, J. (2007). Ruang Publik : Sebuah Kajian Masyarakat Borjuis (terjemahan: Yudi Santoso, Judul Asli: The Struktural Transpormation of the Public Sphere: An Inguiri Into a Category of Baourgeois Society). Penerbit: Kreasi Wacana

Harvey, D. (2009). Neoliberalisme Dan Restorasi Kelas Kapitalis. Penerbit: Resist Book.

Miles, B.M. (2007). Analisis Data Kualitatif (terjemahan oleh : Tjetjep Rohendi Rohidi. Judul asli : Qualitative Data Analysis) Penerbit. Universitas Indonesia.

McGee, T.G. (1971). The Urbanisation Procces in the Third World. London. Bell.

Millassoux, C. (1972). From Reproduction to Production. Economic and Society.

Manning, C. Effendi, T.N. (1996). Urbanisasi, Pengangguran, Dan Sektor Informal Di Kota. Penerbit: Yayasan Obor Indonesia.

Merton, Robert K. (1974). Social Theori and Social Strukture. Edisi direvisi dan diperluas. New York. The Free Press.

Ritzer, G. (2008). Teori Sosial Postmodern (terjemahan oleh : Muhammad Taufik T. Judul 
asli : The Postmodern Social Theory). Yogyakarta. Penerbit: Kreasi Wacana.

Suseno, F.M. (2005). Pemikiran Karl Marx: Dari Sosialisme Utopis ke Perselisihan Revisionisme. Penerbit: PT. Gramedia Pustaka Utama.

Wolf, M. 2007. Globalisasi : Jalan Menuju Kesejahteraan (terjemahan oleh : Samsuddin Berlian) Penerbit: Yayasan Obor Indonesia.

Weber, M. 2007. Etika Protestan dan Semangat Kapitalisme (terjemahan oleh : Yusup
Priyasudiarja. Judul asli : The Protestant Ethic and The Spirit of Capitalism) Penerbit: Jejak.

Yunus, S.H. 2005. Manajemen Kota Prespektif Spasial. Penerbit: Pustaka Pelajar.

Yunus, S.H. 2006. Megapolitan: Konsep, Problematika dan Prospek. Penerbit: Pustaka Pelajar.

Yunus, S.H. 2008. Dinamika Wilayah Peri-Urban Diterminan Masa Depan Kota. Penerbit: Pustaka Pelajar. 